\title{
Juss-Buss [Law Bus]: A Student-run Legal Aid Clinic
}

\author{
Ole Hammerslev, Annette Olesen, \\ and Olaf Halvorsen Rønning
}

\section{Introduction}

One of the strongest brands among alternative legal aid institutions in the Nordic countries is Juss-Buss [Law Bus], the legal clinic run by students of the Faculty of Law of the University of Oslo. Emerging from the radical student movements of the late 1960s and early 1970s and a climate of strong social commitment, law students and young lawyers — such as the Norwegian socio-legal pioneers Thomas Mathiesen, Kristian 'Kikki' Andenæs, and Jon

O. Hammerslev $(\bowtie)$

Department of Law, University of Southern Denmark, Odense M, Denmark

Department of Criminology and Sociology of Law, University of Oslo, Oslo, Norway

A. Olesen

Department of Sociology and Social Work, Aalborg University, Denmark

O.H. Rønning

Department of Criminology and Sociology of Law, University of Oslo, Oslo, Norway

(C) The Author(s) 2018

O. Halvorsen Rønning, O. Hammerslev (eds.), Outsourcing Legal Aid

in the Nordic Welfare States, https://doi.org/10.1007/978-3-319-46684-2_7 
T. Johnsen - became interested in questions concerning access to legal assistance. They not only sought to gain knowledge about structural oppression in Norwegian society but also wanted to make oppressive structures visible, and to change them through so-called action research. Inspired by US trends in outreach legal aid, clinical legal education, and sociology of law (Mathiesen 2001; Capua 1975, 2001) the Norwegian scholars wanted more specifically to combine scientific knowledge with the establishment of legal aid infrastructures benefitting disadvantaged social groups (Hammerslev and Mathiesen 2013; Mathiesen 2011). They initiated a research project that revealed the legal problems of disadvantaged groups and showed there was unmet legal need in the population. The scholars concluded that unmet need was unevenly distributed, being greatest among the most disadvantaged. Current legal aid schemes were failing to alleviate this need. In addition, they found that, in most cases, the provision of legal aid did not improve the lives of the recipients (Eskeland and Finne 1973). Thus, legal aid needed to be provided in situations where there was found to be unmet need, and a concerted effort was required to improve the quality of life of clients. A legal aid outreach initiative was planned, originally just to supply legal information. In order to make it as accessible as possible, it was decided that the clinic should be mobile, which led to the idea of a 'juss-buss' [law bus]. Juss-Buss thus started as a research project in 1971. During the initial phase, the bus was the only office in use. From the very start, the purpose of Juss-Buss was twofold; it would provide legal aid to those in need, and also gather information on the need for legal aid in society, which could be utilised in research reports and in legal policy work (Capua and Juss-Buss 1978). The employees were law students and young lawyers, while the Institute of Sociology of Law, University of Oslo, created a post to help manage the initiative (Capua 2001, p. 12).

The first reports on Juss-Buss highlighted the fact that Juss-Buss clients lacked problem awareness, faced financial barriers, distrusted other public information schemes, and lacked access to affordable lawyers (this was particularly true of clients from rural areas), all of which, along with the clients' more immediate problems led to unmet legal need (Capua 2001). Furthermore, the reports showed that other people also lacked sufficient access to legal aid (Capua 1975). Later research on Juss-Buss based on a similar approach paints much the same picture (Andenæs 1975; Bull and Eidesen 1975; Edvardsen et al., 1975; Johnsen 1987, 1991, 1994, 1999; Juss-Buss 1996, 2001; Rønning \& Juss-Buss 2011). Because of its particular way of 
combining education, legal aid, legal policy work, and research, Juss-Buss is unlike any other Nordic legal aid clinic.

This chapter examines the unique funding, staff recruitment, and case handling structures of Juss-Buss and how for decades it has maintained a strong tradition of legal aid and policy work. The aim of this chapter is, therefore, not to take a critical approach. First, there will be a description of the staff and funding of Juss-Buss, followed by consideration of how the case types and caseload mirror flaws in the welfare state. Second, the workplace organisation of the clinic, and the standardisation of its workflow will be examined, along with an analysis of its staff training, empowerment approach, and case handling structures, that focus explicitly on 'collective work' and outreach legal aid initiatives. Third, there will be a discussion of Juss-Buss' legal policy work, followed by some concluding remarks. ${ }^{1}$

\section{Staff, Funding, and Case Types}

We will now briefly describe Juss-Buss' personnel and funding resources. We will reflect on developments in the number and type of cases JussBuss handles, and relate the figures to changes in the welfare state.

Unlike many other legal aid institutions, such as, for example, Gadejuristen [The Street Lawyers] (see Chap. 8), that struggle for funding, and face budgetary cuts and the implementation of fixed fees (see Sommerlad and Sanderson 2013; Lied 2013), Juss-Buss has been relatively privileged: it has substantial funding, a strong base as a division in the Faculty of Law of the University of Oslo, and students queueing up to volunteer. The work of the Juss-Buss clinic is funded jointly by the Ministry of Justice, the Municipality of Oslo, and a number of charitable organisations. The annual budget is roughly 5 million NOK $(526,315 €)$. In addition, the Faculty of Law and the University of Oslo provide Juss-Buss with offices, IT equipment, and supervisors. The legal basis for the clinic's licence to provide legal aid is the general legislation regarding lawyers and the provision of legal aid, in the Courts of Justice Act. Although licenced lawyers are the main providers of legal aid, the Supervisory Council for Legal Practice has been granted exceptional power to license special legal aid initiatives to provide legal aid. Having this licence, Juss-Buss can provide legal aid on condition that the clinic is supervised by the Faculty of Law, and has adequate quality control mechanisms. 
The daily management of the clinic is carried out by a board, made up of student staff, and a student daily manager, all of whom are supervised by faculty members. The supervisors of the clinic do not take part in the quality control of the handling of individual cases but, by providing basic education and training of new staff members, they contribute to developing and modifying training schemes and quality control. The supervisors also offer support in cases of great complexity, or cases raising particularly difficult ethical questions.

Juss-Buss' personnel consists of around thirty law students, who voluntarily take a year off from their studies to work full-time on legal aid. They then work part-time for one semester. They get the equivalent of one semester's credits for the time they volunteer. The students are paid a small salary, comparable to the monthly student loan. The salary is by no means commensurate with the amount of work they do. In practice, therefore, much of Juss-Buss' work is based on voluntary activity.

\section{Case Types Mirroring Flaws in the Welfare State}

Juss-Buss provides most kinds of legal aid, apart from legal representation in court cases. Juss-Buss, for instance, writes administrative complaints, negotiates divorce settlements or employment disputes, and represents clients in conciliation council. Fig. 7.1 shows the number of cases JussBuss handled from 1990 to 2015.

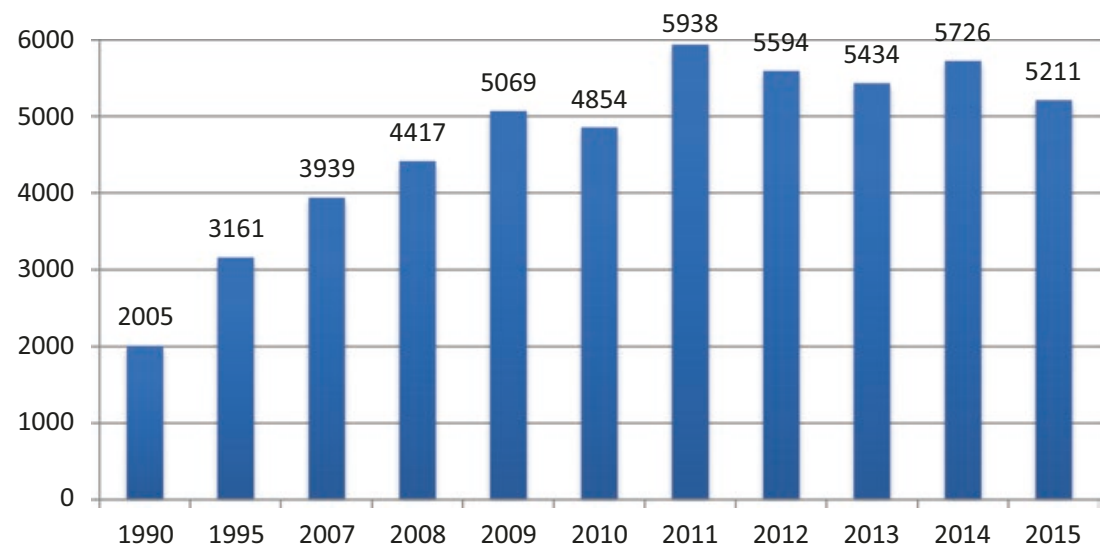

Fig. 7.1 Number of cases in selected years (Skårberg 2016) 
The number of cases has more than doubled since 1990 but has been relatively stable since 2012 . The increase in the number of cases immediately indicates that the need for legal aid increased significantly between 1990 and 2011. However, Skårberg (2016, p. 11) argues that the minor annual variations of cases in the later years do not reflect changes in client demands, but rather indicate developments in the administration of the clinic's outreach legal aid programmes.

Table 7.1 and Fig. 7.2 show Juss-Buss' caseload divided into the clinic's specific key legal disciplines. Most cases concern immigration law, and make up almost one fifth of the cases dealt with in recent years. These are mostly family immigration cases and expulsion cases, which are ineligible for legal aid under the public scheme. The second largest amount of cases involve labour law: most cases are related to unpaid wages and holiday pay, and unlawful dismissal. Most of these cases likewise do not qualify for legal aid under the public scheme. There is also considerable demand for advice on tenancy law, social law, and debt law.

The figures not only reflect Juss-Buss' internal prioritisations of social groups facing some of the most serious problems and vulnerable living situations, but also mirror what research on legal aid and welfare state ideology (see Chaps. 1 and 13) would interpret as flaws in the welfare state. It is possible to identify some social welfare changes and developments in how the caseload is distributed. For example, the increase in debt cases and labour cases has been related to the aftermath of the financial crisis (Arntzen 2009). Similarly the increasing number of cases concerning immigration law between 1990 and 2015 can be linked to parallel

Table 7.1 Number of cases in key legal disciplines, 1999-2015

\begin{tabular}{llllllllll}
\hline & 1999 & 2001 & 2003 & 2005 & 2007 & 2009 & 2011 & 2013 & 2015 \\
\hline Family & 840 & 678 & 643 & 410 & 549 & 733 & 565 & 435 & 366 \\
Tenancy & 878 & 838 & 747 & 461 & 420 & 630 & 668 & 748 & 632 \\
$\begin{array}{l}\text { Social and } \\
\quad \text { national }\end{array}$ & 328 & 248 & 312 & 226 & 355 & 474 & 623 & 611 & 502 \\
$\quad$ insurance & & & & & & & & & \\
Debt & 327 & 350 & 435 & 340 & 350 & 560 & 491 & 439 & 492 \\
Prison & 439 & 237 & 589 & 562 & 353 & 527 & 506 & 467 & 539 \\
Labour & 406 & 446 & 482 & 437 & 510 & 899 & 676 & 727 & 728 \\
Immigration & 339 & 439 & 454 & 590 & 740 & 913 & 1221 & 1007 & 986 \\
\hline
\end{tabular}

Source: Skårberg 2016 


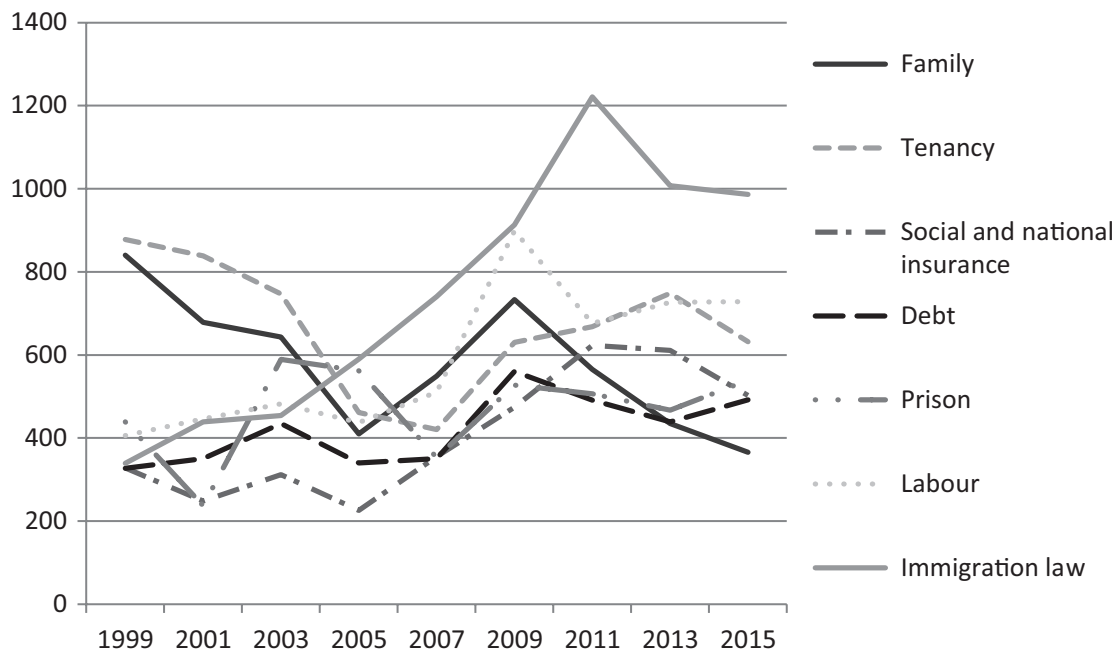

Fig. 7.2 Number of cases in key legal disciplines, 1999-2015 (Skårberg 2016)

developments in the flow of immigrants into Norway. Another parameter related to the increase of cases with an immigration law focus is the hardline foreign policy views that have emerged and gained ground during the same period. Thus, the welfare state does not assist the most disadvantaged citizens with their most basic problems, but civil society organisations have to handle problems the welfare state was set up and expected to handle. What makes the situation even more complex is the fact that Juss-Buss' client groups often have many interrelated legal problems, including claims against welfare state social services. Poor and alienated disadvantaged groups in need of welfare and support services end up in an unequal power struggle with the providers of welfare support-which goes against the values of the universal welfare state (see Olesen 2017). 


\section{Workplace Organisation and Standardisation of Workflow}

Two factors have a significant influence on Juss-Buss' workplace organisation and code of practice for legal aid work. The first is that their licence to provide legal aid is conditional on quality control and supervision, which means they have to devote considerable resources to quality assurance. Quality control is therefore evident in Juss-Buss' organisation and standardisation of workflow, which is based on individual case handling followed by subsequent team processing of cases. The second factor that strongly influences the organisation of Juss-Buss is their target groups. Juss-Buss has always aimed to contact some of the most 'hard-to-reach' and disadvantaged social groups in society. Accordingly, they have adopted an empowering, client-centred approach to outreach legal aid, which also affects their workplace organization, and requires staff to know what the clients' lives are like; i.e., the staff needs to know how to interact with the specific client groups and how to work with them. In what follows, we will focus on how quality control and 'hard-to-reach' disadvantaged groups frame the training and professionalisation of the Juss-Buss staff, their empowerment approach, and their case handling structures. We will explicitly focus on 'collective work' and outreach legal aid initiatives.

\section{Training}

Juss-Buss staff training aims to give a basic introduction to the relevant fields of law, to how relevant legal institutions operate in practice, and to handling clients. Staff is also given basic training in ethics, case preparation, and case processing. The training period is usually short, and provides only brief introductions to the most important topics. Most of the necessary knowledge and skills must be acquired in the course of actual case handling and group work, as — to use the notion of Weber (1978) —a 
form of craft apprenticeship under the guidance of older students. The craft apprenticeship mentality is of pivotal importance, and forms the basis of Juss-Buss' case handling and client contact. Once a case has been taken on, the person responsible for it prepares the case, and presents it in a weekly group meeting in the form of a case summary, with suggestions on how it should be handled. The group meeting consists of six to eight students, including two or three experienced students who have completed their one-year full-time period at Juss-Buss, and now support and supervise the 'newbies'. In the group meetings, the participants comment on each case: the legal statements of facts, the process, administrative procedures, and possible solutions. Juss-Buss' standard procedure prescribes that all further developments in the case must be discussed at group meetings until the case is completed or closed (Johnsen 2003). A member of staff described how the group meetings were focused on giving feedback, even before he started working at Juss-Buss:

'At the job interview, we're asked how we would give and receive feedback on case handling. It makes you reflect from a very early stage on how you'll collaborate with others, and that reflection kinda continues, because we're constantly reminded about the importance of constructive feedback and being cooperative.' (Field notes, Olesen)

The group meetings could be related to Habermas' theory of communicative action, as communication and cooperative actions grounded in mutual dialogue, deliberation, and discussion (see Habermas 1984) serve as the core elements of the outcome of Juss-Buss' group meetings. In a year of full-time work, a Juss-Buss staff member handles between 200 and 250 individual cases, and through group meetings contributes towards around 1500 cases.

\section{Translating the Law into Everyday Language}

The law is a language of symbolic power (Goodrich 1990; Bourdieu 1987) that, among other ways, manifests itself in legal labelling, legal categorisation, different negotiation discourses, and control over meaning, and as an 
instrument and expression of domination (Conley et al. 1978; Goodrich 1990; see also Matoesian 1995; Newman 2013). Lawyers, judges, and legal aid workers, etc., should pay attention to their translation skills. Initially they must translate social problems into legal or non-legal issues (Felstiner et al. 1980/81; Olesen et al. 2017), and when handling a case, it is best if they translate the law into everyday language, to ensure that the clients understand and agree on the legal action being considered. If clients speak a foreign language, the legal aid worker might also have to consider getting an interpreter.

Interaction between clients and legal aid workers might be impeded by differences between the two parties regarding reality-views, vocabulary, and ways of communicating (Sarat and Felstiner 1997; Conley and O'Barr 1990). Attention to the kind of language one uses is therefore of vital importance when approaching disadvantaged social groups, who may lack communication and reading skills (Olesen et al. 2017). Consequently, one of Juss-Buss' key tasks, to which a great part of their craft apprenticeship is devoted, is translating legal language into clientfriendly language. The Juss-Buss staff focuses not only on their spoken interaction with clients, carefully considering and discussing their choice of words, but also takes great pains to make written communication userfriendly. During the Juss-Buss group meetings that were observed the subject of styles of communication was brought up for discussion several times. The students commented on, and tried to improve, each other's oral and written presentations, to make them even clearer and easily comprehensible to their clients (Field notes, Olesen). The focus on language is not just about coping with different styles of speech, but also about being able to translate legal language into comprehensible terms. JussBuss adopts a further 'translation strategy' when they literally translate their booklets, videos, radio features, etc., into English and Arabic.

\section{Referral Service for Clients}

Along with their craft apprenticeship in learning how to translate the law into everyday language, Juss-Buss 'newbies' must also develop skills on the job that enable them to deal with clients in an approachable manner, 
offer support, or - in the best way possible — turn down a request for help. Since Juss-Buss' special legal aid licence determines and limits the services they offer, many clients contact Juss-Buss with legal or non-legal problems that they are not permitted to handle. Drawing on their experience of having to turn down many enquiries, Juss-Buss has developed a professional and standardised procedure for working as 'gatekeepers' dealing with client referrals:

Interviewee_1: 'We try to provide good referrals...'.

Interviewee_2: 'A rather large part of the job is actually doing that, referring [the client] to another person who's working mostly in the particular field that relates to the person's problem ... there are always three people [from the Juss-buss staff] involved in the referral procedure. So, we'll say that we do not work on that specific issue and instead we'll come up with some ideas about who to contact, and then two other staff members must endorse these referrals'.

Interviewee_3: 'We put a lot of work into our referral service because we know that we receive a lot of requests we can't meet. So we try to provide a really good referral service, because we think that is helpful'.

Interviewer: 'And how do you do it? Do you have some kind of booklet?'

Interviewee_2: 'Yes ... and each semester we bring it up to date.' (Interview notes, Olesen)

Juss-Buss has standardised the procedure of disseminating detailed information about where to seek specialist advice outside the domain of Juss-Buss legal aid. Their well-structured referral service for clients is seen as yet another initiative to ensure that the needs of disadvantaged social groups are met.

Apropos the discussion about Juss-Buss' craft apprenticeship, it is worth mentioning a general concern about contradictions in the professional work done by volunteers. As a result of the disparity between administrative and managerial standards on the one hand, and personal, 
impulsive work approaches based on free will on the other (la Cour and Højlund 2008) Juss-Buss could be categorised as a clinic positioned in an organisational mixture of highly-skilled working procedures and 'joint volunteering ownership'. However, this does not seem to be a problem for the professional volunteers involved in Juss-Buss. Instead, the data suggests the clinic to be founded on the rich tradition and fundamental principles of providing outreach legal aid, a tradition that determines the workplace organisation and frames the workflow. Even though Juss-Buss is heavily dependent on volunteers, their working procedures, supervision, and regular group meetings ensure the professional standardisation of their work. Despite this quality control and general supervision, however, the independence of the students working at Juss-Buss is in stark contrast to what happens in many legal clinics in the USA, where there is much closer supervision by faculty staff members or members of the Bar (see Chap. 11).

\section{Outreach Initiatives: With the Aim to Empower and Influence the Political Agenda}

In their attempt to reach the most disadvantaged citizens in society, JussBuss has from the very beginning implemented outreach approaches on many different levels in their legal aid programmes. The term 'outreach work' covers all activities targeting groups with justiciable problems who, for various reasons, do not seek legal advice (see Chaps. 8 and 9; Genn 1999; Genn and Paterson 2001). In the following, we will focus specifically on Juss-Buss' Prison Team, and examine whether their outreach legal aid approaches in prison actually invite people in need to 'troublestalks' and through conversations provide a space for legal and non-legal problems to be voiced. Similar outreach projects are targeted at immigrant education centres, charitable organisations working with Romani people, migrant workers, and children care centres (Skårberg 2016). We will discuss some of Juss-Buss' wide-ranging attempts to inform, educate, and encourage people in need to take action and try to deal with their 
own problems, or seek legal advice. Juss-Buss' outreach legal aid initiatives include work to address inequalities embedded in policy, legal, and institutional frameworks, and to influence policy outcomes. Juss-Buss' legal policy work will be discussed in the closing section.

\section{'Troubles-Talks'}

Most Juss-Buss cases (84\%) come from clients contacting Juss-Buss, either by telephone or in walk-in sessions at the Juss-Buss office; $14 \%$ of cases come (directly) through outreach sessions. However, many clients are encouraged to contact Juss-Buss after an outreach session, because the session itself may be considered an inopportune moment to conduct formal client interviews (Skårberg 2016). Outreach work thus has more impact than the figures indicate. This became clear in a conversation with a Prison Team member, who stressed how contact with a disadvantaged group, such as prisoners, is inextricably linked with outreach legal aid: '... we're convinced that our outreach work, the fact that we visit the prisons, is of great significance and value because only a handful of people call us, but if we come to them-reach out to them-it's easier for them to contact us', (Field notes, Olesen). Criminological studies support the view that some prisoners regard public authorities with distrust and hostility (Ricciardelli et al. 2015; Minke 2012; Olesen 2013), while legal aid research has shown that disadvantaged groups, regardless of their living situation and complex problems, may avoid taking legal action if they have previously had bad experiences with the police and/or legal institutions (Genn 1999; Carlin and Howard 1965; Sejr 1977). Thus, to improve prisoners' access to justice, the Juss-Buss Prison Team visits prisons in and around Oslo on a weekly basis. There are approximately 50 prison visits a year, and they give rise to around 650 cases concerning such issues as social security, debt, immigration, health care, and the terms of sentences (Skårberg 2016).

It is well-known that a large number of justiciable problems never make it to court, or enter any other legal institution. The dark figure of non-registered justiciable problems is also known as the 'tip-of-the-iceberg' 
(Best and Andreasen 1977, p. 701) and "[the] "iceberg problem" in the administration of justice' (Barton and Mendlovitz 1960, p. 30; see also Miller and Sarat 1980/81; Coates and Penrod 1980/81). The infrastructure of legal aid support, therefore, plays an important role in efforts to fight social exclusion, and to ensure access to justice (Eidesen et al. 1975; Genn 1999; Pleasence et al. 2006). Juss-Buss` outreach legal aid prison programme could be seen as enhancing the infrastructure of legal aid support by contacting a disadvantaged group of prisoners, listening to their stories and trying to make them identify and act upon their justiciable problems. However, 'troubles-talks' are sensitive (Jefferson 1988), and call for a trusting relationship developed over time, and consistency from the case manager (Olesen et al. 2017). Since the initial interaction between a new client and a Juss-Buss staff member lasts on average for 15-20 minutes, and the caseload is divided between different staff members, depending on the legal disciplines relevant to the case, it can be difficult to take a client-centred, time-consuming and resourcedemanding approach based on trust. For that reason, the Juss-Buss staff said, it was difficult to do outreach work with prisoners who did not meet them during their prison visits. A Prison Team member explained how the first encounter with a client during an outreach session normally went:

'... usually they'll turn up and say "I need help with this, this is what I need help with". And then we'll look into that specific problem.' Another Prison Team member elaborates by saying '...the ones we meet are those who have decided to ask for help ... and that's very much like "please just take it [the case/problem]!" "Help me now!" "I don't know how to cope with it!". 'But we might only see the tip of the iceberg.' (Interview notes, Olesen)

As reported by the Prison Team members, clients often specify their needs and the help they want to receive but, occasionally, some clients show up with a plastic bag of unopened letters from e.g., debt-collection agencies or public authorities, asking for help to deal with their vague and confused problems (Johnsen 2003). 


\section{Help to Self-Help}

Because they realise that they cannot physically reach many of those who are in need of legal aid, a key element of Juss-Buss' outreach work, besides providing legal aid and information directly via outreach projects, is to raise legal awareness and rights consciousness - these are the terms used by Merry (2003) — among their target groups. To this end, Juss-Buss tries to establish grievance structures by empowering e.g., prisoners to reflect on their problems, voice them, and potentially take legal action. The aim is to make clients more aware of the availability of legal assistance, and the possibility of contacting Juss-Buss at a later stage, if they experience a need for legal aid. One of the ways Juss-Buss tries to establish and strengthen grievance structures among prisoners is by broadcasting information about prisoners' legal rights, and how specific justiciable problems can be dealt with, on the prison radio station 'Bandit Radio':

“'Do you have the details of your debt? If not, you'll find a pamphlet with information on how to manage your debt and your contact prison officer must help you with this! If you do not get any help, call Juss-Buss..." [These slots] are aired between radio programmes, in various languages.' (Field notes, Olesen)

The radio slots are supported by helping access to the legal system by providing education, self-help programmes, and self-help materials. For less complex legal issues, self-help kits may be the most empowering and quickest problem-solving approach. For example, Juss-Buss has launched a self-help debt project providing prisoners with easily accessible step-bystep informational videos, forms and letter templates in plain language, to encourage them to take matters into their own hands (see e.g., JussBuss 2012).

The self-help approach differs significantly from trust-building 'troubles-talks' with disadvantaged people who are in need of face-to-face interaction and somebody to tell about their problems, before they can seek the help they need. However, educational self-help initiatives may establish easy understandable grievance structures, and procedures that enable the 'hard-to-reach' group to view their social problems in a legal 
context, and show them possible strategies to address them via Juss-Buss (see Hoffmann 2003).

\section{Legal Policy Work}

'I'm met with the smell of fresh paint when I come into the Juss-Buss office, and I soon notice a group of staff members lying on the floor, which is covered with large pieces of white fabric. Excitement and enthusiasm fill the room as the students write slogans on the banners in red paint. A young girl raises her head and says with a smile that they're getting ready for a march supporting the rights of refugees.' (Field notes, Olesen).

Juss-Buss' activist approach, combined with legal policy work, is of great importance in furthering their interest in change-making. A JussBuss staff member explains:

'We're very conscious that we have a strong legal aid inheritance. That's why we reacted so fiercely when the government suddenly decided that our appropriation could only be used on case handling, not on legal policy work. Juss-Buss has always stood on two legs, and the activist approach can't be removed without destroying the basic idea. So we protested, and used the media, and luckily we won, and the government backed down. We mainly based our protests on the fact that we could not be under the thumb of a party or a government. We do legal policy work, and work with a wide range of parties to promote what we consider best for our client group. And fortunately, they [the politicians] are very good at using us and listening to our opinions.' (Interview notes, Olesen)

Juss-Buss has always paid careful attention to case registration and to recording information about their client groups, to build up a unique stock of empirical knowledge about the lives and complex legal needs of 'hard-to-reach' groups. This accumulation of knowledge, underpinned by Juss-Buss' strong brand and network-which includes many former JussBuss staff members who now occupy high positions in public life-is mobilised to make sure their clients' voices are heard, and that their legal 
problems are in the news and on the political agenda. Juss-Buss' legal policy work is thus about informing debates and legislation that affect their client groups, about briefing politicians on the law in practice, and also, on real people's experiences, and about identifying and processing test cases. When Juss-Buss, after careful deliberation over their legal tactics, addresses specific test cases, the aim is not just to achieve a certain result in the individual case, but to get news coverage that lays bare society's social structures and legal barriers, in order to benefit their client groups by changing the law in a certain field. A side effect is to promote Juss-Buss as a pro-active brand in the area of the legal rights of disadvantaged groups.

Juss-Buss is not only active in Norway. It is also involved in various international legal aid projects. The main objective of these collaborations is to help establish, support, or develop similar legal aid clinics. Such projects have been launched in e.g., China, Vietnam, Poland, Lithuania, and Croatia.

\section{Concluding Remarks}

This chapter has shown how Juss-Buss was established in connection with action research projects conducted by visionary critical socio-legal scholars at the University of Oslo in the early 1970s. The outreach legal clinic was inspired by similar US outreach legal aid work and its governing principle was that it should both provide legal aid to disadvantaged groups, and collect information about the clients' legal needs and background for use in research and policy work to improve the life situations of the client groups.

Since its establishment, Juss-Buss has played an important role in providing outreach legal aid to disadvantaged groups that would otherwise struggle to name their legal problems, and claim their rights in core welfare areas where the welfare state has abdicated its social responsibility, and instead assumed the position of the opposing party.

Like other legal clinics, Juss-Buss relies on student volunteers, who obtain credits for their work. The high staff turnover has necessitated a form of training involving internal craft apprenticeship, through which 
the students not only learn how to meet and communicate with the client groups but also adapt to the strong culture and values of Juss-Buss, which include a commitment to do legal policy work.

An important aspect of Juss-Buss' work is outreach legal aid to prisoners. In outreach work, the staff aims to build trust in order to be able to start 'troubles-talks', and thus help transform prisoners' problems into legal terms. However, prisoners are hard to reach, so Juss-Buss also tries to establish grievance structures that inform, educate, and empower prisoners to voice their problems, use the Juss-Buss self-help-kits or seek help.

The other important task that Juss-Buss undertakes is legal policy work, and it is in a unique position to do so: First, they have a long tradition, and a strong brand supported by their position in the Faculty of Law of the University of Oslo; second, they have a strong network of former Juss-Buss students occupying important positions in the legal field; and finally, they have exceptional data covering the legal needs of different social groups and their complex legal challenges, and life situations of their client groups. In order to move beyond individual cases and improve the client groups' lives at a societal level, Juss-Buss tries to play an active role in setting the political agenda and influencing law making, to address the social problems of their client groups, together with the legal and structural causes of these problems.

\section{Notes}

1. The chapter is based on Olesen's and Hammerslev's observation studies and interviews and on Rønning's experiences as daily manager and legal aid worker in Juss-Buss.

\section{References}

Andenæs, K. (1975). Rettshjelp til norske sigøynere. In A. Eidesen, S. Eskeland, \& T. Mathiesen (Eds.), Rettshjelp og samfunnsstruktur (pp. 118-152). Oslo: Pax. Arntzen, S. B. (2009). Årsrapport for Juss-Buss 2009 (Vol. 117). Oslo: Juss-buss, Institutt for kriminologi og rettssosiologi, Universitetet i Oslo. 
Barton, A., \& Mendlovitz, S. (1960). The experience of injustice as a research problem. Journal of Legal Education, 13, 24-39.

Best, A., \& Andreasen, A. R. (1977). Consumer response to unsatisfactory purchases: A survey of perceiving defects, voicing complaints, and obtaining redress. Law \& Society Review, 11(4), 701-742.

Bourdieu, P. (1987). The force of law: Toward a sociology of the juridical field. The Hastings Law Journal, 38, 805-853.

Bull, S., \& Eidesen, A. (1975). Rettshjelp til herbergister. In A. Eidesen, S. Eskeland, \& T. Mathiesen (Eds.), Rettshjelp og samfunnsstruktur (pp. 152-186). Oslo: UniPax.

Capua, G. D. (1975). Juss-Buss - Et rettshjelpstilbud for "vanlige folk"? In A. Eidesen, S. Eskeland, \& T. Mathiesen (Eds.), Rettshjelp og samfunnsstruktur (pp. 72-94). Oslo: Pax.

Capua, G. D. (2001). Om å legge ut på dypet. Oslo: Institutt for kriminologi og rettssosiologi, Avdeling for rettssosiologi, Universitetet i Oslo.

Capua, G. D., \& Juss-Buss. (1978). Virksomheten i Juss-Buss i 1977/Gunnar de Capua (Vol. 16). Oslo: Universitetet i Oslo, Inst.for rettssosiologi.

Carlin, J. E. \& Howard, J. (1965). Legal representation and class justice. U.C.L.A Law Review, 12(2), pp. 381-437.

Coates, D., \& Penrod, S. (1980/81). Social psychology and the emergence of disputes. Law \& Society Review, 15(3/4), pp. 655-680.

Conley, J. M., \& O'Barr, W. M. (1990). Just words: Law, language, and power. Chicago: Chicago University Press.

Conley, J. M., O’Barr, W. M., \& Lind, E. A. (1978). The power of language: Presentational style in the courtroom. Duke Law Journal, 78, 1375-1399.

Edvardsen, O. B. E., Langbach, T., Svennebye, H., \& Aakvaag, T. (1975). Rettshjelp til fremmedarbeidere i Norge. In A. Eidesen, S. Eskeland, \& T. Mathiesen (Eds.), Rettshjelp og samfunnsstruktur (pp. 95-117). Oslo: Pax.

Eidesen, A., Eskeland, S., \& Mathiesen, T. (1975). Rettshjelp og samfunnsstruktur. Oslo: Pax.

Eskeland, S., \& Finne, J. (1973). “Rettshjelp”: En analyse og empirisk undersøkelse av tradisjonell rettshjelps muligheter og begrensningerserlig for folk som lever under vanskelige økonomiske eller sosiale kår. Oslo: Pax.

Felstiner, W., Abel, R., \& Sarat, A. (1980/81). The emergence and transformation of disputes: Naming, blaming, claiming. Law \& Society Review, 15(3/4), pp. 631-654. 
Genn, H. (1999). Paths to justice: What people do and think about going to law. Oxford: Hart Publishing.

Genn, H., \& Paterson, A. (2001). Paths to justice. Scotland: What people in Scotland think and do about going to law. Oxford: Hart Publishing.

Goodrich, P. (1990). Legal discourse studies in linguistics, Rhetoric and Legal Analysis. Houndsmills: Palgrave Macmillan.

Habermas, J. (1984). Theory of communicative action. Boston: Beacon Press.

Hammerslev, O., \& Mathiesen, T. (2013). Marxistisk retssociologi. In O. Hammerslev \& M. R. Madsen (Eds.), Klassisk og moderne retssociologi. Centrale temaer og tekster. København: Hans Reitzels Forlag.

Hoffman, E. A. (2003). Legal consciousness and dispute resolution: Different disputing behavior at two similar taxicab companies. Law \& Social Inquiry, 28(3), 691-716.

Jefferson, G. (1988). On the sequential organization of troubles-talk in ordinary conversation. Social Problems, 35(4), 418-441.

Johnsen, J. T. (1987). Retten til juridisk bistand: en rettspolitisk studie. Oslo: TANO.

Johnsen, J. T. (1991). Juss-Buss and clinical legal education (Vol. 51). Oslo: University of Oslo.

Johnsen, J. T. (1994). Nordic legal aid. (Sweden, Finland, Norway) (legal aid). Maryland Journal of Contemporary Legal Issues, 5(2), 301-331.

Johnsen, J. T. (1999). Progressive legal services in Norway? International Journal of the Legal Profession, 6(3), 261-310.

Johnsen, J. T. (2003). Juss-buss-et fagkritisk eksperiment: idégrunnlag, arbeidsprinsipper og erfaringer: veiledning for medarbeidere i Juss-Buss. Oslo: Juss-Buss.

Juss-Buss. (1996). Juss-Buss 25 ar: 1971-1996: jubileumsfestskrift. Oslo: Juss-buss.

Juss-Buss. (2001). Tvers igjennom lov til seier. Oslo: Unipax.

Juss-Buss. (2012). The Prisoner's handbook 2012. Juss-buss' guide to prison matters. Olso: Juss-Buss.

la Cour, A., \& Højlund, H. (2008). Voluntary social work as a paradox. Acta Sociologica, 51(1), 41-54.

Lied, C. (2013). Gatejurister: Oppsøkende rettshjelp til folk med rusrelaterte problemer. Oslo: Akademika forlag.

Mathiesen, T. (2001). Juss-Buss 30 år. In Juss-Buss (Ed.), Tvers igjennom lov til seir (pp. 16-19). Oslo: Pax Forlag. 
Mathiesen, T. (2011). Retten i samfunnet: en innforing $i$ rettssosiologi (6. utg). Oslo: Pax.

Matoesian, M. G. (1995). Language, law, and society: Policy implications of the Kennedy smith rape trial. Law \& Society Review, 29(4), 669-702.

Merry, S. (2003). Rights talk and the experience of law: Implementing women's human rights to protection from violence. Human Rights Quarterly, 25(2), 343-381.

Miller, R. E., \& Sarat, A. (1980/81). Grievances, claims, and disputes: Assessing the adversary culture. Law \& Society Review, 15(3/4), pp. 525-566.

Minke, L. K. (2012). Fangsletsindreliv. København:Jurist-og Økonomforbundets Forlag.

Newman, D. (2013). Legal aid lawyers and the quest for justice. Oxford: Hart Publishing.

Olesen, A. (2013). Løsladt og geldsat. København: Jurist- og Økonomforbundets Forlag.

Olesen, A. (2017). Released to the "battlefield" of the Danish welfare state: A battle between support and personal responsibility. In T. Ugelvik \& P. S. Smith (Eds.), Scandinavian penal history, culture and prison practice (pp. 271-295). Palgrave Macmillan.

Olesen, A., Nielsen, S. P. P., \& Hammerslev, O. (2017). Gadejura - kunsten at fremelske gadefolkets oplevelse af at bære rettigheder. In N. J. Clausen et al. (Eds.), Festskrift til professor Hans Viggo Godsk Pedersen (pp. 435-455). København: Jurist- og Økonomforbundets Forlag.

Pleasence, P., Buck, A., \& Balmer, N. (2006). Causes of action: Civil law and social justice. London: Legal Services Research Centre.

Ricciardelli, R., Maier, K., \& Hannah-Moffat, K. (2015). Strategic masculinities: Vulnerabilities, risk and the production of prison masculinities. Theoretical Criminology, 19(4), 491-513.

Rønning, O. H., \& Juss-Buss (Eds.). (2011). Med loven mot makta: Juss-Buss forti år. Oslo: Novus.

Sarat, A., \& Felstiner, W. L. F. (1997). Divorce lawyers and their clients: Power and meaning in the legal process. New York: Oxford University Press.

Sejr, L. E. (1977). Retshjalp $i$ et lokalområde. Aarhus: Aarhus Universitet.

Skårberg, H. H. (2016). Årsrapport for Juss-buss 2015. Oslo: Juss-Buss stensilserie. 
Sommerlad, H., \& Sanderson, P. (2013). Social justice on the margins: The future of the not for profit sector as providers of legal advice in England and Wales. Journal of Social Welfare and Family Law, 35, 305-327.

Weber, M. (1978). Economy and society. Berkeley: University of California Press.

Open Access This chapter is distributed under the terms of the Creative Commons Attribution 4.0 International License (http://creativecommons.org/ licenses/by/4.0/), which permits use, duplication, adaptation, distribution, and reproduction in any medium or format, as long as you give appropriate credit to the original author(s) and the source, a link is provided to the Creative Commons license, and any changes made are indicated.

The images or other third party material in this book are included in the work's Creative Commons license, unless indicated otherwise in the credit line; if such material is not included in the work's Creative Commons license and the respective action is not permitted by statutory regulation, users will need to obtain permission from the license holder to duplicate, adapt or reproduce the material.

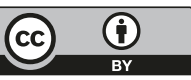

